\title{
CANDID SCIENCE V
}

\section{Conversations with Famous scientists}


This page intentionally left blank 


\section{CANDID SCIENCE V}

Conversations with Famous Scientists

\section{Balazs Hargittai}

\section{István Hargittai}


Published by

Imperial College Press

57 Shelton Street

Covent Garden

London WC2H 9HE

\section{Distributed by}

World Scientific Publishing Co. Pte. Ltd.

5 Toh Tuck Link, Singapore 596224

USA office: 27 Warren Street, Suite 401-402, Hackensack, NJ 07601

UK office: 57 Shelton Street, Covent Garden, London WC2H 9HE

Balazs Hargittai

Saint Francis University

117 Evergreen Drive

Loretto, Pennsylvania 15940, USA

István Hargittai

Budapest University of Technology and Economics

Eötvös University and Hungarian Academy of Sciences

H-1521 Budapest, Pf. 91, Hungary

\section{Library of Congress Cataloging-in-Publication Data}

Hargittai, Balazs.

Candid science V : conversations with famous scientists / Balazs Hargittai, István Hargittai.

p. $\mathrm{cm}$.

Includes index.

ISBN 1-86094-505-8 (alk. paper) -- ISBN 1-86094-506-6 (pbk. : alk. paper)

1. Scientists--Interviews. 2. Scientists--Biography. 3. Scientists--History--20th century.

4. Mathematicians--Interviews. 5. Mathematicians--Biography. 6.

Mathematicians--History--20th century. I. Title: Candid science five. II. Title: Candid science 5. III. Hargittai, István, IV. Title.

Q141.H264 2005

$509^{\prime} .2 ' 2--\mathrm{dc} 22$

[B]

2004062538

\section{British Library Cataloguing-in-Publication Data}

A catalogue record for this book is available from the British Library.

Copyright @ 2005 by Balazs Hargittai and István Hargittai

All rights reserved. This book, or parts thereof, may not be reproduced in any form or by any means, electronic or mechanical, including photocopying, recording or any information storage and retrieval system now known or to be invented, without written permission from the Publisher.

For photocopying of material in this volume, please pay a copying fee through the Copyright Clearance Center, Inc., 222 Rosewood Drive, Danvers, MA 01923, USA. In this case permission to photocopy is not required from the publisher. 


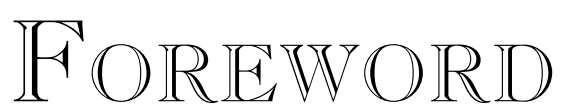

I feel greatly honored to be given the task to write this Foreword. It has been a great pleasure to go through the fascinating interviews of yet another nearly two scores of scientists by the Hargittais. What strucks me this time as much as before is the enormous individual variation of the characters exposed, making every story unique. Whether such variation is peculiar to scientists, or to human beings in general, or perhaps even to other species, is beyond me. However, one can easily identify an important element that all these individuals have in common: curiosity. Again, one can ask if this is something peculiar to scientists. In this case I feel inclined to answer yes. Admittedly, the exploratory drive rests on a fundamental instinct of profound survival value that all human beings and a great number of other species have in common. In childhood the response to novelty is a lot more dramatic than later in life. As we grow older our curiosity loses some of its intensity, which is perhaps a sign of maturity. Maybe a common feature of scientists is a slow maturation process, at least in this regard.

An interview, like an autobiography, is of course not an impartial statement. As time goes by we tend to remodel our reminiscences, perhaps to make them more palatable for our self-esteem. People involved in one and the same event will thus often describe it and their role in it differently. For the historian it must therefore be of utmost value to have access to as many personal accounts as possible of a scientific discovery. In this regard autobiographies and interviews are complementary. An advantage of the interview is that the interviewer can bring aspects into focus that the interviewee might otherwise tend to pass by. In any event it will remain for 
the historian to scrutinize all relevant documents in order to come as close to the objective "truth" as possible.

It is remarkable how the Nobel Prize has been able to keep its top position over the years. One may wonder why. At the outset the announcement of the Prize must have been astounding, considering its size and its scope. Subsequently, the Nobel Foundation and the institutions involved in the evaluation process have apparently done a sufficiently good job to keep up the reputation. The existence of such a Superprize is, however, not unproblematic. To some extent this has to do with Alfred Nobel's Testament. First of all, it brings into focus a distinct, prizeworthy discovery. In fact, the discovery should preferably have been made during the year preceding the award, even though earlier discoveries could be taken into account provided their importance were not immediately obvious. These stipulations should perhaps be viewed against Nobel's own astounding discoveries of dynamite and the like, even though it would be unfair to blame the richly gifted Alfred Nobel for simple-mindedness. Nevertheless, the emphasis of a distinct discovery has probably left out a number of outstanding pioneers who have opened up new important fields without necessarily contributing with any specific discovery. It may have been difficult for the various Nobel Committees to deal with this problem in some cases. In any event it is obvious that the prizeworthy candidates outnumber the laureates and that the actual outcome will often depend on a number of more or less relevant circumstances. It is regrettable that this fact is not always considered enough and that consequently some prizeworthy candidates feel unnecessarily disappointed.

Once again, the Hargittais are to be congratulated on yet another masterful Candid Science volume. It will certainly be enjoyed by a great number of enthusiastic readers.

Göteborg, January 2005

Arvid Carlsson 


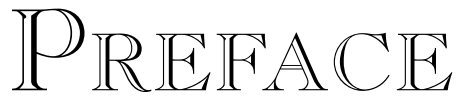

In this fifth volume of the Candid Science series, there are some departures from the previous volumes in the approach of the compilation of the material. The present volume as a whole is not classified as physics, chemistry or biomedical sciences, but keeping with cross- and inter-disciplinarity, it contains entries from all these disciplines and, in addition, from mathematics. There is only a loosely-followed sequence in the volume, going from mathematics to physics to chemistry and to the biomedical sciences.

Another peculiarity of this volume is that it includes nine interviews from another project, the Larson Tapes. The story behind it is as follows. In 1998, I recorded a conversation with Clarence Larson (contained in this volume) and learned about the project he and his wife Jane had been doing, called "Pioneers of Science and Technology". Clarence and Jane (video) recorded conversations with famous scientists and technologists. By the time we met, they had collected over sixty recordings. They gave us a copy of a few conversations and my wife (Magdolna Hargittai, Magdi in short) and I published some edited transcripts from them in addition to my Larson interview in the magazine The Chemical Intelligencer.

In 1999, Clarence died and Jane donated all the original tapes in their collection to us, encouraging us to use them to the benefit of a wider readership. She stated in her letter of April 14, 1999:

In recognition of your activities in recording interviews with outstanding scientists in The Chemical Intelligencer and elsewhere, including the interview with my late husband Clarence E. Larson incorporating excerpts from Clarence's interview with Luis 
Alvarez and the article based on Clarence's Wigner interview, I am giving you all of Clarence's interview tapes. I am doing so with the understanding that you and Magdi will try to bring out articles using this interview material, possibly even producing a book based on this material. I am very much in support of your doing this in the interest of disseminating the knowledge and information Clarence had accumulated on these tapes. You have my permission and my blessing for your activities related to these tapes.

We started a series from the Larson Tapes in the magazine, but the magazine folded soon and the tapes laid idle for some years. Recently the idea came up to use some entries of the Larson Tapes in the Candid Science series and hence nine of the Larson interviews are included in the present volume. They are dispersed among the Hargittai interviews as found reasonable in the sequence of the volume, but clearly identified as Larson Tapes.

The original Larson interviews are of a different character from our interviews; they greatly differ also from each other, and we did not try to make a uniform presentation out of them. In some cases we merely produced an abbreviated narrative, in other cases some annotated excerpts and in yet other cases we tried to reproduce the whole interview in near completeness. We are grateful to Charles Townes, who - in addition to his own Larson interview - agreed to review the material of the Schawlow Larson interview as well. In the case of Dr. Townes, we also recorded our own interview, and the two interviews - twenty years apart - nicely augment each other. For the Fowler interview, we received help from his two former associates and especially from Charles Barnes of the Kellogg Laboratory of the California Institute of Technology. The Pauling transcripts were reviewed by Zelek Herman, Linus Pauling's long-time associate. There has already been a Pauling entry in the Candid Science series, viz., in the very first volume; however, that was a very brief interview, one of the last, if not the very last, Linus Pauling granted before his death. We are happy to have a longer exposure of this great scientist in this volume. To augment the Dulbecco interview, we asked Paul Berg to share his experience with him. In his own interview (see, Candid Science II, pp. 154-181), Dr. Berg mentioned Renato Dulbecco's impact on his research career and this was a good occasion to ask Dr. Berg to tell us more about it.

For our original contact with the Larsons, we have to thank Arnold Kramish with whom I had come into contact when I was editing The Chemical Intelligencer. Arnold Kramish served in the Manhattan Project 
and, later, with the U.S. Atomic Energy Commission. He served as a consultant to the U.S. government and industry. He is the author of many books and articles on nuclear history. In his letter of May 27, 1997, he suggested to me and my wife to get in contact with the Larsons, and I am quoting from his letter:

On September 2, 1944, I suffered a near-fatal accident at an installation of the Manhattan Project. Colonel Stafford Warren, chief physician of the Manhattan Project, intervened on my care, and to him I credit much of the fact that I am here today. By chance, his daughter, Jane became my valued and efficient secretary after the war at RAND.

Enter Clarence Larson, who, during the war, was an associate of E. O. Lawrence at Berkeley in developing the electromagnetic method of isotope separation. He then became head of that project at Oak Ridge. After the war, he was placed in charge of all Manhattan Project - then Atomic Energy Commission (AEC) - isotope separation. Eventually, he became an AEC Comissioner. He married my secretary, Jane, the daughter of Colonel Warren.

Through the years, Jane has become an accomplished and internationally-known ceramicist, specializing in murals for scientific buildings. For example, the mural at the AAAS [American Association for the Advancement of Science] building is hers. She has just been awarded the commission to do the mural for the chemistry building at the University of Maryland.

We are happy that with the nine Larson interviews communicated in this volume, we are able to pay tribute to Clarence Larson's memory and express our appreciation to Jane Larson's generosity.

Readers will notice that a new Hargittai name appears on the cover of the present volume. Balazs is our son and although his research interest, peptide chemistry, is far from our structural chemistry, he has shared our general interest in science history and scientists.

The technique of the Hargittai interviews has been described repeatedly in the Prefaces to previous volumes and it has not changed. We record an informal conversation and later submit the slightly edited transcripts to the interviewee for checking, changing, and augmenting. Very few interviewees do not respond to our sending them the transcripts; most do and improve the presentation without changing the flavor of live conversation. In some 
cases there were repeated cycles of improvement. My interviewing approach is different from that of a journalist. Not only am I not trying to press for answers in cases where I sense reluctance on the interviewee's part, I do not mind the interviewee's changing of what had been said, in the subsequent exchange. I want the interviewee to feel relaxed during the interview and comfortable with the final product. I know I lose some following this approach, but I believe we all gain too because the interviewee senses this interviewee-friendliness and collegiality, and in most cases opens up more to a sympathetic colleague than to an aggressive journalist. The interview is a joint product in the final account; it reflects on both of us; and I believe that we both try to do our best in bringing forth an insight into both science and the individual scientist.

With this, I am not saying that on occasions I would not have liked to get more information than what had been offered. A case in point was the Damadian controversy in the Lauterbur interview. I knew very little about the story, I knew primarily about the unprecedented newspaper ads protesting the Nobel decision in the Physiology or Medicine Prize for the year 2003, the fact that Dr. Damadian was left out from it. Some colleagues had warned me not even to try asking Paul Lauterbur about it. However, I did, and my questions were not brushed away, rather, I understood that this was a topic that Paul had been exposed to saturation and the long story behind it had caused him and his family pain and much unpleasantness. Nonetheless, Paul gave me meaningful responses and he pointed to a book that helped me assess of what had happened. When I sent him the transcripts, he barely changed anything, and found my treatment of the issue sensitive.

The book Paul Lauterbur gave me is Donald P. Hollis's Abusing Cancer Science: The Truth about NMR and Cancer (The Strawberry Fields Press, Chehalis, Washington, 1987). From this book I would like to quote a few passages that are appreciative with respect to Damadian's contributions. I am doing this because in my reading, the newspaper ads and the hoopla around them have created a notion that might mask the value of Dr. Damadian's real contributions. In addition, it is a sad consequence of the Nobel Prize that those who are left out in most cases are not even accorded an "honorable mention" in Nobel dealings. The Nobel Prize - even if it may not be the intention of the Nobel Prize committees - often contributes to rewriting science history. From this point of view, it is worthwhile to quote a few brief excerpts from Hollis's book what seems to me an objective evaluation of Damadian's contribution (pp. 174-175): 
Damadian had clearly made a provocative contribution to medical NMR when he showed the differences in relaxation times between the normal and malignant rat tumors and suggested that they might be used to diagnose cancer in humans. That provided a reason for further study of cell NMR and a goal for the early imagers. No one that I know of has ever denied Damadian credit for that contribution. Most people, sensitive to Damadian's desire for credit, emphasize that this idea, at least with respect to cancer, is Damadian's and his alone.

Damadian's cancer work gave Lauterbur a reason to invent imaging.

Lauterbur had the idea of making pictures of the human body by NMR and he invented and quickly demonstrated a practical way to do it. It is not difficult to imagine the feelings and disappointment of a person like Damadian when he realized that his observations had played a role in calling Lauterbur's attention to the fact that tissues of the body had different NMR properties and that had he possessed Lauterbur's education, background and more general view of science, he, himself, might have been the one to invent NMR imaging.

I would have been interested in meeting Dr. Damadian and including a conversation with him in this volume; I wrote to him inviting him for an interview. I was willing to visit him; alas, I received no response.

There was a controversy of a somewhat different kind around the 2000 Nobel Prize in Physiology or Medicine and I am pleased that all three laureates and also Dr. Hornykiewicz agreed to record a conversation with me. In this case, the person who was left out, Dr. Hornykiewicz, did not wage a protest to be sure, but many on his behalf did. Whereas in the case of the 2003 Nobel Prize in Physiology or Medicine where there was an unused third slot, in the case of the 2000 prize, all three slots were filled; nobody questioned the prize-worthiness of any of the awardees; however, the prize could have been formulated in other ways as well beside the way it was formulated and with other compositions of the laureates.

There was no controversy in the 2000 Chemistry Nobel Prize, yet I would have loved to interview Hideki Shirakawa in addition to Alan MacDiarmid and Alan Heeger; alas, it did not happen. The most intriguing question to 
Shirakawa would have been about his Korean colleague who for the first time - quite by accident - produced the conducting polyacetylene polymer. There have been various versions of this accidental discovery, which was the foundation from which the work emerged that was ultimately awarded the Nobel Prize to Heeger, MacDiarmid, and Shirakawa. In his e-mail of April 30, 2002, Shirakawa gave me the name of the Korean scientist, Dr. Hyung Chick Pyon and clarified what happened: "It is rumored that the silvery form of polyacetylene film was discovered as a consequence of a linguistic misunderstanding between the visiting Korean scientist and me. But this is totally incorrect. He was a fluent speaker of Japanese because he was educated in Japanese while Korea was occupied by Japan for 35 years before World War II."

As I have written, this interviews project is merely a Hargittai hobby, being a side product of our main activities. As travel takes us to places, mostly lecture invitations and, to a smaller extent, family vacations, we try to use them to cultivate our side interests. In the [European] Summer of 1999 I was invited to a visiting professorship at the University of Auckland in New Zealand. Magdi and I organized the trip in such a way as to include a stopover in Bangkok and to interview Princess Chulabhorn, who is also a research chemist. Herbert Brown [Candid Science I, pp. 250-269] made the connection between us. Hence a most unusual encounter took place.

In addition to the acknowledgments already expressed above, I would like to thank the following for invitations and hospitality extended to us that made some of the interviews possible: Richard Henderson and the MRC Laboratory of Molecular Biology in Cambridge in 2000, James Watson at the Cold Spring Harbor Laboratory in 2002, Ingemar Ernberg at the Karolinska Institute in 2003, Alex Varshavsky at the California Institute of Technology in 2004, and Gunther Stent at Berkeley, California, in 2004.

Balazs would like to mention his postdoctoral stay at the University of Arizona in Tucson that brought us to the meeting with Donald Huffman (and Wolfgang Krätschmer) and express his appreciation to Miss Amy K. Croskey, a student of Saint Francis University for her assistance in transcribing some of the Larson interviews. We are both grateful to Magdi for her letting us include a couple of her interviews in this volume and for her untiring support and help in bringing this project to completion. I am grateful to the Budapest University of Technology and Economics and the Hungarian Academy of Sciences as well as to the Hungarian National Scientific Research Funds for their support of our research activities in structural chemistry. 
Balazs is grateful to Saint Francis University in Loretto, Pennsylvania, for support and encouragement.

We note with appreciation that some of the entries - often in a somewhat different form - had appeared — as always duly noted — in The Mathematical Intelligencer, The Chemical Intelligencer, Chemistry International, and Chemical Heritage (in the latter with Alfred Bader's generous support).

Budapest

István Hargittai

Loretto, Pennsylvania

Balazs Hargittai 
This page intentionally left blank 


\section{CONTENTS}

Foreword $\quad \mathrm{v}$

Preface vii

H. S. M. (Donald) Coxeter 2

$\begin{array}{ll}\text { John H. Conway } & 16\end{array}$

Roger Penrose 36

Alan L. Mackay $\quad 56$

$\begin{array}{ll}\text { Dan Shechtman } & 76\end{array}$

$\begin{array}{ll}\text { Charles H. Townes } & 94\end{array}$

$\begin{array}{ll}\text { Arthur L. Schawlow } & 138\end{array}$

$\begin{array}{ll}\text { Leon N Cooper } & 164\end{array}$

Alexei A. Abrikosov 176

$\begin{array}{ll}\text { Luis W. Alvarez } & 198\end{array}$

$\begin{array}{ll}\text { William H. Pickering } & 218\end{array}$

$\begin{array}{ll}\text { William A. Fowler } & 228\end{array}$

Vera C. Rubin 246

Neta A. Bahcall 266 
xvi Hargittai \& Hargittai, Candid Science V

Rudolf E. Peierls

Emilio G. Segrè

Harold Agnew

Clarence E. Larson

Nelson J. Leonard

Princess Chulabhorn

Linus Pauling

Miklós Bodánszky

Melvin Calvin

Donald R. Huffman

Alan G. MacDiarmid 400

Alan J. Heeger

Jens Christian Skou

Paul C. Lauterbur

Gunther S. Stent

John E. Sulston

Renato Dulbecco

Paul Berg on Renato Dulbecco

Baruch S. Blumberg

Arvid Carlsson

Oleh Hornykiewicz

618

Paul Greengard

Eric R. Kandel

Name Index 


\section{Other books by István Hargittai}

Candid Science IV: Conversations with Famous Physicists, Imperial College Press, London, 2004 (with M. Hargittai).

Our Lives: Encounters of a Scientist, Akadémiai Kiadó, Budapest, 2004.

Candid Science III: More Conversations with Famous Chemists, Imperial College Press, London, 2003.

The Road to Stockholm: Nobel Prizes, Science, and Scientists, Oxford University Press, Oxford, 2002 (paperback edition 2003).

Candid Science II: Conversations with Famous Biochemical Scientists, Imperial College Press, London, 2002.

Candid Science: Conversations with Famous Chemists, Imperial College Press, London, 2000.

In Our Own Image: Personal Symmetry in Discovery, Kluwer/Plenum, New York, 2000 (with M. Hargittai).

Upptäck Symmetri! (Discover Symmetry!, in Swedish), Natur och Kultur, Stockholm, 1998 (with M. Hargittai).

Symmetry through the Eyes of a Chemist, Second edition, Plenum, New York, 1995. Symmetry: A Unifying Concept, Shelter Publications, Bolinas, CA, 1994 (with M. Hargittai).

The VSEPR Model of Molecular Geometry, Allyn \& Bacon, Boston, 1991 (with R.J. Gillespie).

The Structure of Volatile Sulphur Compounds, Reidel, Dordrecht, 1985.

The Molecular Geometries of Coordination Compounds in the Vapour Phase, Elsevier, Amsterdam, 1977 (with M. Hargittai).

\section{Edited books}

Strength from Weakness: Structural Consequences of Weak Interactions in Molecules, Supermolecules, and Crystals, Kluwer, Dordrecht, 2002 (with A. Domenicano). Symmetry 2000, Vols. I-II, Portland Press, London, 2002 (with T.C. Laurent). Advances in Molecular Structure Research, Vols. 1-6. JAI Press, Greenwich, CT, 19952000 (with M. Hargittai).

Combustion Efficiency and Air Quality, Plenum, New York, 1995 (with T. Vidóczy). Spiral Symmetry, World Scientific, Singapore, 1992 (with C.A. Pickover).

Fivefold Symmetry, World Scientific, Singapore, 1992.

Accurate Molecular Structures, Oxford University Press, Oxford, 1992 (with A. Domenicano).

Quasicrystals, Networks, and Molecules of Fivefold Symmetry, VCH, New York, 1990. Symmetry 2: Unifying Human Understanding, Pergamon Press, Oxford, 1989.

Stereochemical Applications of Gas-Phase Electron Diffraction, Vols. A-B, VCH Publishers, New York, 1988.

Crystal Symmetries, Shubnikov Centennial Papers, Pergamon Press, Oxford, 1988 (with B.K. Vainshtein).

Symmetry: Unifying Human Understanding, Pergamon Press, Oxford, 1986.

Diffraction Studies on Non-Crystalline Substances, Elsevier, Amsterdam, 1981 (with W.J. Orville-Thomas). 